\title{
Snail assemblages in Holocene floodplain research - an example from the southern Caucasus
}

\author{
Hans von Suchodoletz ${ }^{1}$, Christiane Richter ${ }^{2}$, Frank Walther ${ }^{3}$, Marcel Bliedtner ${ }^{4}$, Mariam Eloshvili ${ }^{5}$, \\ Levan Losaberidze $^{6}$, and Bernhard Hausdorf ${ }^{3}$ \\ ${ }^{1}$ Institute of Geography, Leipzig University, Johannisallee 19a, 04103 Leipzig, Germany \\ ${ }^{2}$ Institute of Geography, Technische Universität Dresden, Helmholtzstrasse 10, 01069 Dresden, Germany \\ ${ }^{3}$ Zoological Museum, Universität Hamburg, Martin-Luther-King-Platz 3, 20146 Hamburg, Germany \\ ${ }^{4}$ Institute of Geography, Friedrich Schiller University Jena, Löbdergraben 32, 07743 Jena, Germany \\ ${ }^{5}$ Bioarchaeology Department, University of Warsaw, Krakowskie Przedmieście 26/28, 00-927 Warsaw, Poland \\ ${ }^{6}$ Society of Young Archaeologists of Georgia, Kipiani 4, 0119 Tbilisi, Georgia
}

Correspondence: Hans von Suchodoletz (hans.von.suchodoletz@uni-leipzig.de)

Relevant dates: $\quad$ Received: 3 June 2020 - Revised: 9 October 2020 - Accepted: 2 November 2020 Published: 14 December 2020

How to cite:

von Suchodoletz, H., Richter, C., Walther, F., Bliedtner, M., Eloshvili, M., Losaberidze, L., and Hausdorf, B.: Snail assemblages in Holocene floodplain research - an example from the southern Caucasus, E\&G Quaternary Sci. J., 69, 247-260, https://doi.org/10.5194/egqsj-69-247-2020, 2020.

Abstract:

During the last decades, rivers and their deposits in different regions were intensively studied to better understand the late-Quaternary landscape evolution and former human activities. One proxy for paleoecological and paleoclimatic reconstructions is the analysis of gastropods (snails) from carbonatic river sediments. In the scope of this study, we investigated gastropod assemblages from a Holocene fluvial sediment-paleosol sequence at the upper Alazani River in the southeastern Caucasus. On the one hand, we aimed to derive reliable independent information about possible long-lasting human activity since the late Neolithic-Chalcolithic in the upper Alazani floodplain. This was formerly suggested by $n$-alkane biomarker vegetation reconstructions from the fluvial sediments. However, the reliability of that method is still debated. On the other hand, we aimed to obtain reliable information about a formerly suggested, possibly tectonic-driven, large-scale shift of the river course during the Late Holocene. In agreement with the $n$-alkane biomarkers, our results demonstrate that the studied site was free of the natural forests during the Early and Middle Holocene until ca. $4.5 \mathrm{cal} \mathrm{kyr} \mathrm{BP}$. Since this contrasts with a pollen-based vegetation reconstruction from a neighboring floodplain that was covered with forests during that time, the open vegetation in the upper Alazani valley was probably caused by continuous settlement activity as is also indicated by archeological finds in the sequence. Therefore, using our paleoecological proxies it is possible that we identified a settlement center in the upper Alazani floodplain that was populated from the late Neolithic-Chalcolithic. This center was not known thus far, since the settlement remains are covered by thick floodloam today that hindered their detection during archeological surface surveys. Therefore, our findings suggest that the area in the southern Caucasus region that was settled during the late-Neolithic-Chalcolithic period should have been larger than was known thus far. Furthermore, increasing contributions of wetland gastropods since ca. 4 cal kyr BP confirm a local shift of the river course towards the investigated site during the Late Holocene, possibly linked with ongoing tectonic activity. However, in contrast to former 
suggestions our gastropod assemblages indicate a slow rather than abrupt process. Our study demonstrates the high value of gastropod assemblages for geoarcheological and geomorphological research in floodplains with carbonatic river sediments at both a regional and local spatial scale.

Kurzfassung:

Für ein besseres Verständnis der spätquartären Landschaftsentwicklung und früherer menschlicher Aktivitäten wurden während der letzten Dekaden in verschiedenen Regionen Flüsse und deren Ablagerungen intensiv untersucht. Einen Proxy für paläoklimatische und paläoökologische Rekonstruktionen stellen Analysen von Gastropoden (Schnecken) aus karbonatischen Flusssedimenten dar. Während dieser Studie wurde die Artenzusammensetzung von Gastropodengemeinschaften einer holozänen Sediment-Paläobodensequenz am oberen Alazani im südöstlichen Kaukasus untersucht. Zum einen wollten wir fundierte unabhängige Informationen über mögliche landandauernde menschliche Aktivitäten in der Aue des oberen Alazani seit dem Spätneolithikum/Chalcolithikum erhalten. Eine solche Besiedlung legte bereits eine frühere auf $n$-Alkan-Biomarkern basierende Vegetationsrekonstruktion aus den fluvialen Sedimenten nahe, jedoch ist die Verlässlichkeit jener Methode bis heute umstritten. Zum anderen wollten wir fundierte Informationen über eine vermutete tektonisch verursachte großmaßstäbige Flusslaufverlagerung im Spätholozän erhalten. In Übereinstimmung mit der früheren Biomarkerstudie zeigte sich, dass der Untersuchungsstandort bis ca. 4.5 cal. ka BP nicht die natürlicherweise vorkommende Waldvegetation aufwies. Im Gegensatz dazu zeigen Pollenuntersuchungen einer benachbarten Flussaue das gleichzeitige Vorherrschen von Wald. Dieser Unterschied lässt sich vermutlich durch kontinuierliche Siedlungsaktivität am oberen Alazani erklären, was auch durch archäologische Funde aus der fluvialen Sequenz selbst gestützt wird. Somit konnten wir mittels unserer paläoökologischen Untersuchungen vermutlich ein seit dem Spätneolithikum/Chalcolithikum bestehendes Siedlungszentrum am oberen Alazani identifizieren. Dieses war bisher unbekannt, da die Siedlungsreste heute durch mächtigen Auenlehm überdeckt sind und somit während archäologischer Oberflächenbegehungen nicht entdeckt werden können. Somit ist es möglich, dass das während des Spätneolithikums/Chalkolithikums im südlichen Kaukasus besiedelte Gebiet größer war als bisher bekannt. Außerdem zeigen zunehmende Anteile feuchtigkeitsliebender Gastropoden seit ca. 4 cal. ka BP eine lokale Verlagerung des Flusslaufs in Richtung des Untersuchungsstandorts während des Spätholozäns an, was vermutlich durch andauernde tektonische Aktivität am Südrand des Großen Kaukasus verursacht wurde. Im Unterschied zu früheren Annahmen zeigen die Gastropen aber eine langsame und keine schnelle Verlagerung. Unsere Studie demonstriert den hohen Wert der Analyse von Gastropodenverteilungen in Flussauen mit kalkreichen Flusssedimenten für geomorphologische und geoarchäologische Fragestellungen sowohl auf einer regionalen als auch lokalen räumlichen Skala.

\section{Introduction}

River systems react sensitively towards different external influences such as tectonics, base level fluctuations, climate changes and anthropogenic activities. Therefore, rivers and their deposits were intensively studied in different regions during the last decades to decipher the late-Quaternary landscape evolution (Bridgland and Westaway, 2008; Schulte et al., 2015; Faust and Wolf, 2017; von Suchodoletz et al., 2015, 2018a, b; Avsin et al., 2019; Lauer et al., 2020). In addition, floodplains were preferred areas of former human activities due to easy access to water resources, fertile loamy soils and a generally flat topography. Therefore, during the last years they were also intensively studied in the context of geoarcheological research (Hassan, 1997; Morozova, 2005; Giosan et al., 2012; von Suchodoletz and Faust, 2018).
Geomorphological and geoarcheological research of floodplains and their sediments is generally carried out by (i) field-based geophysical and geomorphological analyses partly supported by digital elevation or multispectral remote sensing data (Bakker et al., 2007; Mlekuz and Budja, 2010; Syvitsky et al., 2012; von Suchodoletz et al., 2015; Babek et al., 2018) and (ii) stratigraphical and sedimentological analyses of naturally or artificially outcropped sediment sections or drilling cores. The obtained fluvial sediments are analyzed and numerically dated using sedimentological, geochemical and geochronological methods (Fuchs et al., 2011; Giosan et al., 2012; Schulte et al., 2015; von Suchodoletz et al., 2015, 2018a, b; Faust and Wolf, 2017; Avsin et al., 2019; Lauer et al., 2020). In addition, under favorable conservation conditions local and regional paleoecological and paleoclimatic information can also be obtained based on biogenic proxies such as plant macrofossils, charcoal pieces, pollen grains, di- 
atoms or leaf wax biomarkers (Kittel et al., 2016; Scott et al., 2016; Bliedtner et al., 2018a). Furthermore, similar to other sediment archives such as loess-paleosol and dunepaleosol sequences or colluvial deposits (Moine et al., 2008; Faust et al., 2015; New et al., 2019; Richter et al., 2019), also species distribution and/or isotopic composition of gastropods from carbonate-rich fluvial sediments were investigated for paleoecological and paleoclimatic reconstructions during the last years (Fuhrmann, 2008; Zielhofer et al., 2010; Murelaga et al., 2012; Alexandrowicz, 2013; Juřričková et al., 2013; Granai and Limondin-Lozouet, 2018).

During this study, we analyzed the species distribution of gastropods from a Holocene fluvial sediment-paleosol sequence at the upper Alazani River in the southeastern Caucasus that was formerly investigated by von Suchodoletz et al. (2018b). Current carbonate contents of sediments and paleosols between $11 \%$ and $42 \%$ allowed for excellent preservation of gastropods throughout the sequence. So far, Holocene malacological studies from the region mainly focused on marine or coastal fauna (Lahijani et al., 2009; van de Velde et al., 2019), whereas most terrestrial paleoecological studies were carried out using pollen analyses in lakes or peat bogs (Connor and Kvavadze, 2008; Messager et al., 2013, 2017; Joannin et al., 2014; Leroyer et al., 2016; Connor et al., 2018). The first goal of our study was to derive reliable independent information about possible long-lasting human activity in the floodplain since the late Neolithic-Chalcolithic as was formerly suggested by $n$-alkane biomarker vegetation reconstructions from the fluvial sediments (Bliedtner et al., 2018a, 2020). Although the $n$-alkane biomarker vegetation reconstruction was successfully backed by a study on recent $n$ alkanes from the region (Bliedtner et al., 2018b), the reliability of this method is still debated (Bush and McInerney, 2013). The second goal of this study was to obtain reliable independent information about a formerly suggested largescale shift of the river course during the Late Holocene that was possibly linked with regional tectonic activity (von $\mathrm{Su}-$ chodoletz et al., 2018b).

\section{Study area}

\subsection{Study area}

The $240 \mathrm{~km}$ long Alazani River originates from the southern slope of the central Greater Caucasus in eastern Georgia at ca. $2800 \mathrm{~m}$ a.s.l. and finally flows into the Kura River that drains into the Caspian Sea (Fig. 1a). About $40 \mathrm{~km}$ from its source the Alazani joins with its right tributary Ilto, which also originates from the southern slope of the central Greater Caucasus at an altitude of ca. $2300 \mathrm{~m}$ a.s.l. After their confluence, the river mostly runs in the Alazani thrust top basin between the southern foothills of the Greater Caucasus in the northeast (Adamia et al., 2010) and the Kura fold-and-thrust belt in the southwest (Kura FTB; Forte et al., 2010). The investigated exposure at the northwestern tip of the Alazani basin is located ca. $10 \mathrm{~km}$ downstream from the confluence and has a subcatchment of ca. $1100 \mathrm{~km}^{2}$ (Fig. 1b). From the confluence onward, the Alazani basin has a width between 4 and $12 \mathrm{~km}$ and widens toward the east. Here, the braided river has a width between 250 and $600 \mathrm{~m}$, and its course is deflected by frontal folds and thrusts of the Greater Caucasus bivergent orogen (Forte et al., 2014). The gravelly current floodplain is limited toward the south by a scarp of ca. 5-7 m that crops out fine-grained overbank deposits (Fig. 1b). These sediments form part of a mainly flat surface with a maximal width of ca. $10 \mathrm{~km}$ that gradually rises toward the Kura FTB in the south. The surface is dissected by several small creeks that originate from the Kura FTB in the south and are canalized today. As is also indicated by a well-developed recent soil on its top, this surface cannot be flooded by the Alazani River today. In contrast, the northern slope is mostly rather gradual. Ca. 5-9 km west of the studied site, wellrecognizable gravelly former river channels subparallel to the recent river course are found up to $1.5 \mathrm{~km}$ northward from the recent riverbed (Fig. 1c). These were suggested to represent the former riverbed that was abandoned due to a large-scale shift of the river course during the Late Holocene (von Suchodoletz et al., 2018b).

The upper Alazani basin, in which the study site is located, receives ca. $720 \mathrm{~mm}$ of annual precipitation, with a peak during spring and early summer that is caused by convective events (Lydolph, 1977). Mean annual temperature is about $12.0^{\circ} \mathrm{C}$ (http://de.climate-data.org/location/28480/, last access: 13 April 2017, station: Akhmeta). Accordingly, the discharge maximum of the Alazani River between April and June is dominated by both snowmelt in the Greater Caucasus and the annual precipitation maximum; i.e., the river has a pluvio-nival runoff regime. The natural vegetation of the semi-humid upper Alazani basin consists of deciduous elm-oak-vine forests (Quercus pedunculiflora, Ulmus foliacea and Vitis sylvestris; Connor and Kvavadze, 2008). However, agricultural fields and grasslands cover most of the recently inactive elevated valley floor that is outcropped by the investigated sequence, whereas the active modern floodplain hosts scattered patches of deciduous riparian forests (Alnus barbata and Salix excelsa).

\subsection{Studied section}

The investigated fluvial sediment-paleosol sequence $\left(42^{\circ} 02^{\prime} 17.7^{\prime \prime} \mathrm{N}, 45^{\circ} 21^{\prime} 18.7^{\prime \prime} \mathrm{E}\right.$; $450 \mathrm{~m}$ a.s.l. $)$ is naturally exposed with a thickness of up to $7 \mathrm{~m}$ along the right bank of the upper Alazani River and was formerly investigated by von Suchodoletz et al. (2018b). The stratigraphy was mapped over a distance of ca. $250 \mathrm{~m}$ along the river, and the sediments between 800 and $700 \mathrm{~cm}$ were retrieved by hand drilling. Sedimentary analyses (carbonate content, total organic carbon, $\mathrm{pH}$ and mass-specific magnetic susceptibility) were carried out to distinguish in situ paleosols from often similar-looking soil sediments. Furthermore, grain 


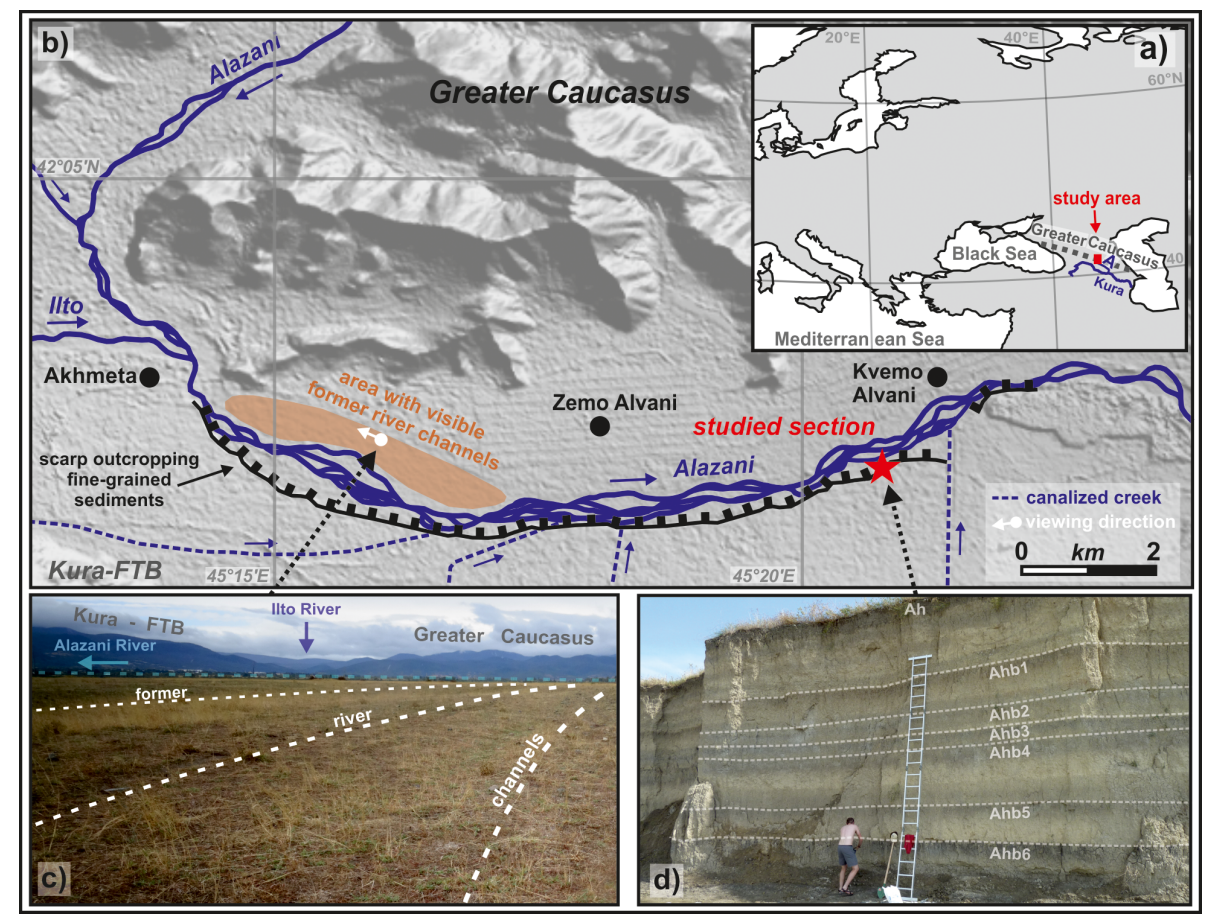

Figure 1. (a) Location of the study region (letter "A" showing the Alazani River). (b) Map of the study area at the southern foothill of the Greater Caucasus. DEM (digital elevation map) source: ALOS (Advanced Land Observing Satellite) Science Project, Earth Observation Research Center (EORC) and Japan Aerospace Exploration Agency (JAXA). (c) Photo of an area with visible former river channels north of the current riverbed. (d) Photo of the investigated fluvial sediment sequence with highlighted (paleo-)soils.

sizes were analyzed to better characterize the stratigraphy. Here we give a short overview of the chronostratigraphy of the studied section, and more details can be found in von Suchodoletz et al. (2018b) (Fig. 1d).

The sequence mostly consists of fine-grained silty to clayey overbank sediments (generally $>50 \%$ clay) with some intercalations of coarser-grained sandy to pebbly material. Six blackish-greyish to reddish paleosols (Ahb1 to Ahb6) have formed in situ in these sediments, and a welldeveloped soil (Ah) has formed on the recent surface (Fig. 2). All paleosols could be followed over longer distances along the outcropped sequence, demonstrating the representativeness of the stratigraphy. Three intensively developed paleosols (Ahb1, Ahb5 and Ahb6) show distinct upper but gradual lower boundaries, and three weakly developed paleosols (Ahb2, Ahb3 and Ahb4) show gradual upper and lower boundaries. The age model is based on seven AMS (accelerator mass spectrometry) radiocarbon-dated charcoal pieces that were found to be in the stratigraphic order, whereas two ages had to be rejected, since they were older than the datings of underlying deposits (von Suchodoletz et al., 2018b). The non-overestimated ages range between 8.0 and $8.2 \mathrm{cal} \mathrm{kyr} \mathrm{BP}$ $(95.4 \%)$ in the upper part of Ahb6 and 1.6 and $1.8 \mathrm{cal} \mathrm{kyr} \mathrm{BP}$ $(95.4 \%)$ in the sediments below the recent soil Ah. By using a soil development index and by referencing this index with the approximate age of the recent soil Ah, approximate durations of soil formation were calculated for all paleosols by the differences of the four sedimentary proxies (von Suchodoletz et al., 2018b). The oldest radiocarbon age of 8.0$8.2 \mathrm{cal} \mathrm{kyr} \mathrm{BP}$ was obtained from a charcoal piece that was found together with archeological artifacts (potsherds, bones and obsidian tools) in the upper part of Ahb6. These artifacts were classified as late Neolithic-Chalcolithic, and a fireplace in the same stratigraphic position indicates that they originate from a local settlement and were not transported towards this site (Fig. 2). The radiocarbon age of 2.4-2.7 cal kyr BP was obtained from charcoal that was found together with numerous Iron Age archeological artifacts (potsherds, bones) in the upper part of uppermost paleosol Ahb1 (Fig. 2), and singular potsherds were also found between Ahb5 and Ahb4 as well as in Ahb4.

\section{Methods}

For the mollusk analyses, we took 12 samples with $10 \mathrm{~L}$ of sediment each. These comprised six samples from paleosols and six samples from fluvial sediment layers of the fluvial sediment sequence (Fig. 2). The sediment was wet-sieved to obtain the fraction $>500 \mu \mathrm{m}$. Subsequently, all macroscopically visible shells and shell fragments were separated. The shell remains were determined using a Wild M3Z stereomi- 


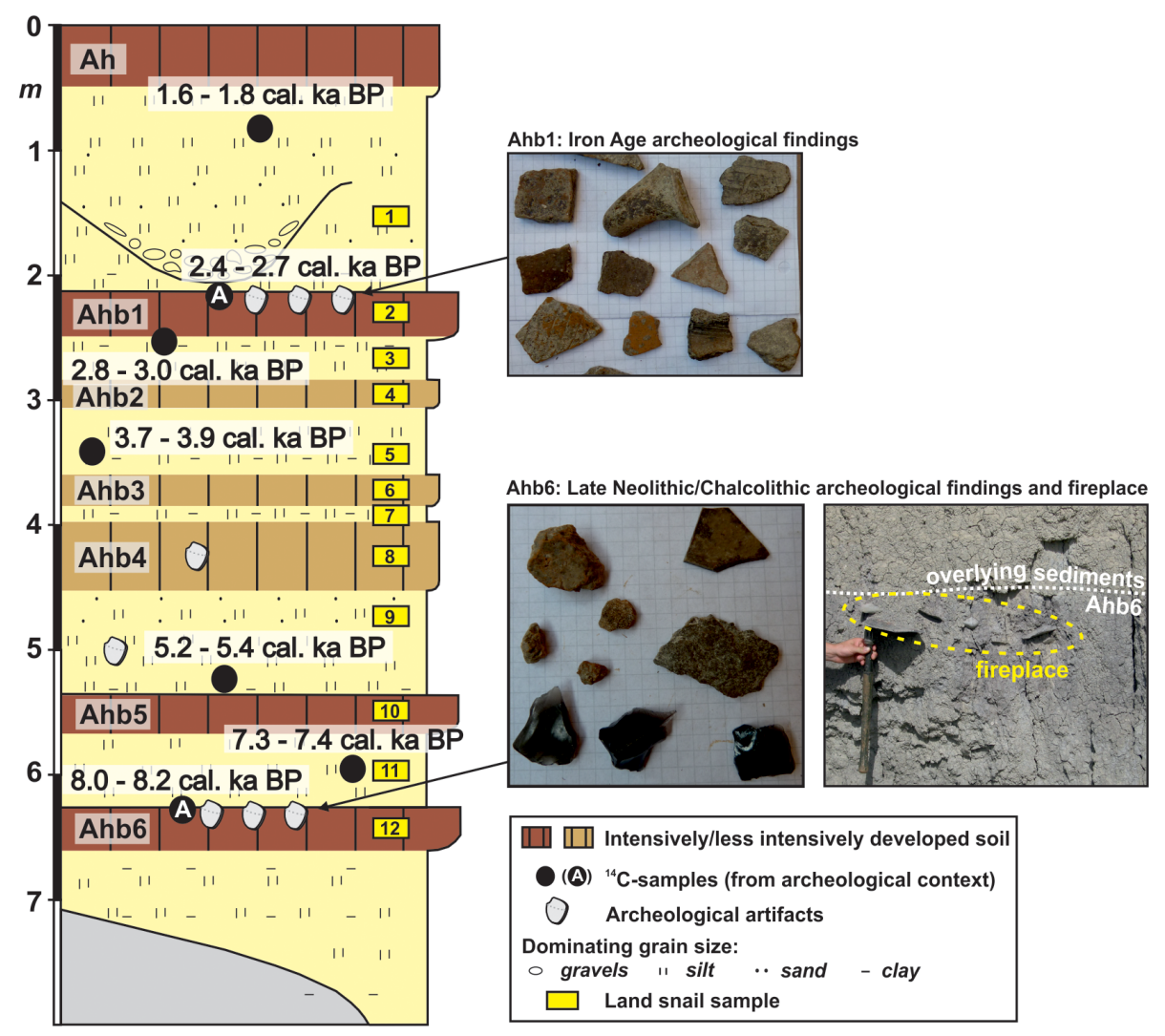

Figure 2. Stratigraphical sketch of the sequence with sampling positions of gastropods; photos of Iron Age findings in the upper part of Ahb1 and late-Neolithic-Chalcolithic findings and a fireplace in the upper part of Ahb6.

croscope with 20- to 40-fold magnification. We used species richness as a measure of diversity.

We used an approach similar to that of Ložek (1964) and Juřičková et al. (2014) for the classification of the gastropod species into ecological groups. With regard to the general habitat, we classified the species into open-country, generalists and woodland species, and with regard to humidity requirements we distinguished wetland and aquatic species. The allocation of the taxa to the ecological groups is shown in Fig. 3.

\section{Results}

A total of 13 gastropod species were extracted from the investigated fluvial sediment sequence, namely Pomatias rivularis (Eichwald, 1829), Galba truncatula (Müller, 1774), Cecilioides acicula (Müller, 1774), Punctum pygmaeum (Draparnaud, 1801), Oxyloma elegans (Risso, 1826), Chondrula tridens (Müller, 1774), Vallonia costata (Müller, 1774), Vallonia pulchella (Müller, 1774), Vertigo pusilla (Müller, 1774), Vitrea pygmaea (Boettger, 1880), Helix lucorum (Linnaeus, 1758), Xeropicta derbentina (Krynicki, 1836), and Harmozica ravergiensis (Férussac, 1835) (Figs. 3 and 4). All species found in the sediments still live in the catchment of the Alazani River. Cecilioides acicula is a burrowing species. Therefore, it is possible that at least a part of the specimens of this species found in sample 3 originates from overlying paleosol Ahb1. However, excluding this species from the following analyses would not affect any of the conclusions.

The quantitative and qualitative gastropod distribution across the sequence (Figs. 3 and 5; species list in Supplement Table S1) indicated a succession from open-country assemblages to woodland assemblages and a subsequent reduction of woodland in the youngest layer: the lowermost three samples (samples 12 to 10) were dominated by Vallonia pulchella and Chondrula tridens, which are species of open grassland. In sample 9 Harmozica ravergiensis, a species characteristic to open shrub- to woodlands appeared for the first time. During the formations of layers 9 to 6 the transition from grassland assemblages to assemblages dominated by species characteristic for woodland occurred. This transition was accompanied by an increase in species richness. The lithological units from which samples 5 to 2 were taken were dominated by forest species (Vallonia costata, Vertigo pusilla, Pomatias rivularis and Harmozica ravergiensis) and show high species richness. Samples 7 to 4 contain Vitrea pygmaea, a species associated with open xerothermic forests or bushland. Sample 2 contained a high number of Poma- 


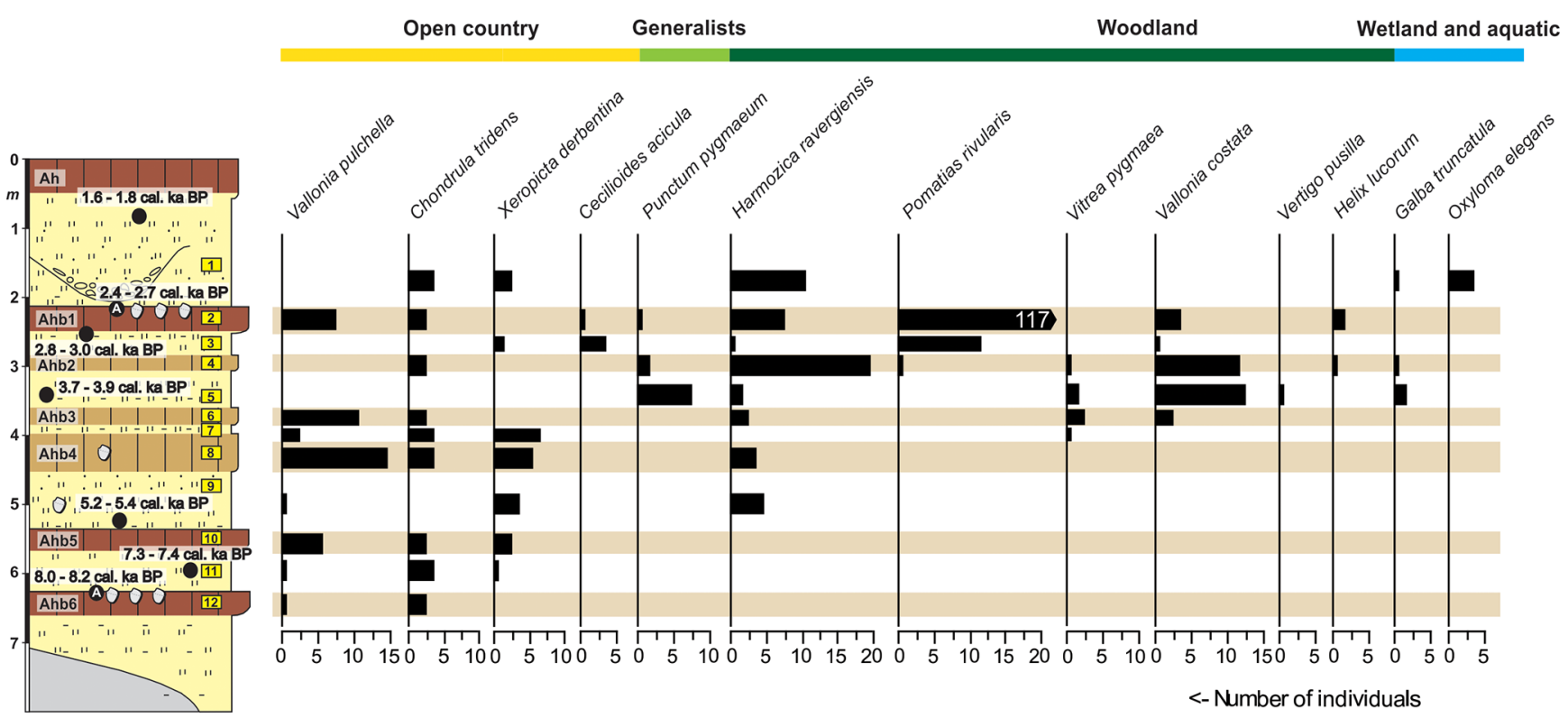

Figure 3. Quantitative distribution of gastropods in the investigated fluvial sediment sequence and their ecological classification. For the legend of the stratigraphy please see Fig. 2.

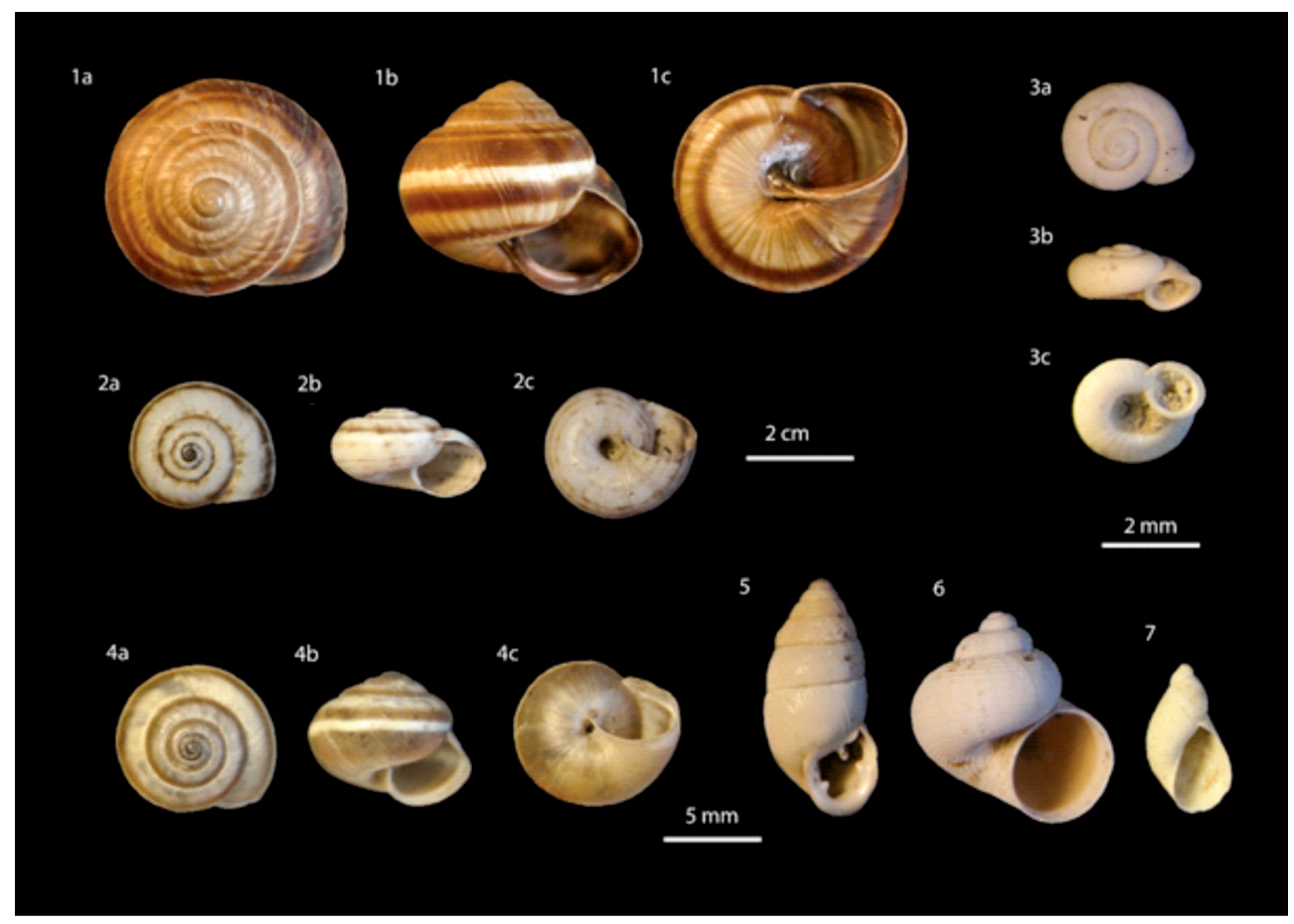

Figure 4. (1) Helix lucorum (a: apical view, b: apertural view and c: umbilical view), (2) Xeropicta derbentina, (3) Vallonia costata, (4) Harmozica ravergiensis, (5) Chondrula tridens, (6) Pomatias rivularis, (7) Oxyloma elegans.

tias rivularis, which might be the result of floods that accumulated thick-walled shells, or it might indicate a human disturbance of the vegetation cover. The latter possibility might be supported by a parallel high number of the opencountry species Vallonia pulchella and Chondrula tridens. In sample 1 all characteristic forest species disappeared. This layer is characterized by a mix of open-country and openwoodland species.

The freshwater snail Galba truncatula inhabiting temporary pools and the riverbank-inhabiting Oxyloma ele- 


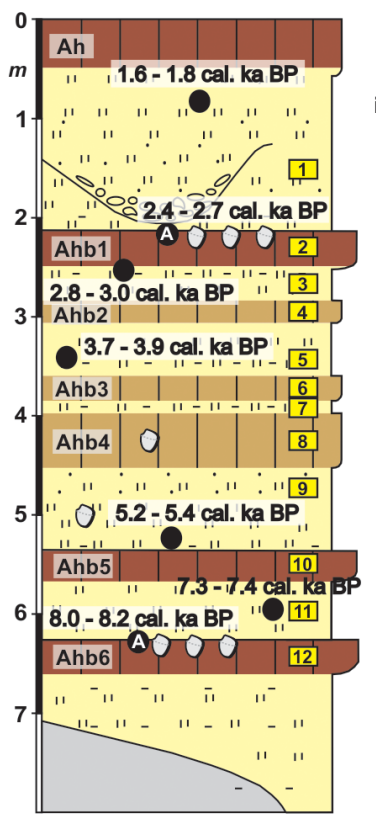

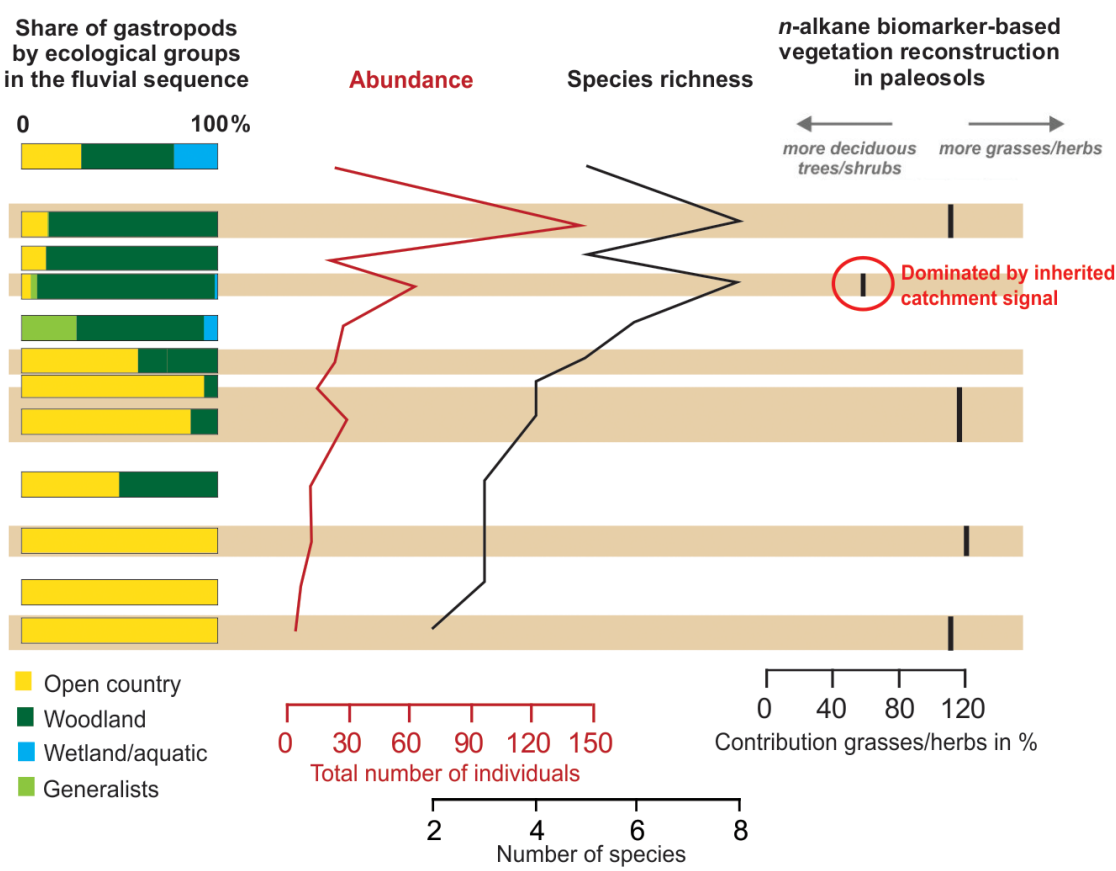

Figure 5. Percentages of ecological groups of gastropods, abundance and species richness of the gastropod assemblages in the investigated fluvial sediment sequence and comparison with a formerly derived vegetation reconstruction based on $n$-alkane biomarkers (Bliedtner et al., 2018a). Please note that the "contribution grasses/herbs" is a semi-quantitative estimate, and uncertainties of this approach can cause percentages $>100 \%$. For the legend of the stratigraphy please see Fig. 2.

gans were completely missing in the older samples (12-6), whereas they were present in most of the younger samples (5-1).

\section{Discussion}

\subsection{The Holocene gastropod assemblages of the upper Alazani floodplain}

If we compare the gastropod assemblages of the paleosols with those of the non-pedogenic fluvial sediment layers, there are hardly any differences in species composition, but the former show higher abundances (Figs. 3 and 5). Higher abundances in the paleosols are probably caused by the longer exposure times at the stable surfaces of the paleosols favoring shell preservation. This is a typical phenomenon related to paleosols (Ložek, 1990). Whereas the samples from the paleosols probably contain mainly specimens that lived at or near the site under investigation, the samples from fluvial sediments may also contain shells from more distant places upstream. Therefore, if there had been forest in the upstream vicinity at the time of formation of the deeper layers, some individuals of woodland species would probably be present in the fluvial samples. Consequently, the congruence of the trends seen in the samples of fluvial sediments and of paleosols indicates that the observed succession from open-country assemblages in samples 12 to 10 and transi- tional assemblages with a mix of open-country and openwoodland species in samples 9 to 6 to assemblages dominated by forest species in samples 5 to 2 (Figs. 3 and 5) is regional rather than restricted to the investigated site. Species of undisturbed forest ecosystems and deadwood specialists such as Caspicyclotus sieversi, Acanthinula aculeata, Vitrea contortula and Scrobifera taurica are completely missing. These species would indicate an old-growth beech forest as it exists today on the slopes of the source area of the Alazani River and its tributaries (Pokryszko et al., 2011; Mumladze et al., 2017). Instead, species of sparse forests and wooded scrubland dominate samples 7 to 2 . Accordingly, the parallel occurrence of Chondrula tridens and Harmozica ravergiensis implies a mosaic-like arrangement of wooded scrubland and open areas. There are several possibilities to explain this special composition: (i) this could partly be caused by the proximity to the active riverbed, as indicated by the occurrence of wetland species from sample 5 upward. Likewise, Myšák and Horsák (2011) showed that riparian forests in the Czech Republic hosted different gastropod faunas compared to more distant hillside forests. More humid conditions in riparian forests led to a lower tree cover and a significantly higher coverage of the herb layer. Furthermore, although the fluvial sediments may contain shells from more distant places upstream, given that the fluvial sediments contained few individuals in total, the likelihood to record rare species from undisturbed forest far upstream is low. (ii) The high propor- 
tion of ubiquitous and drought-tolerant species even in samples 5 to 2 and the low species richness compared to natural forest ecosystems are typical of ecosystems that are influenced by humans. Therefore, it is possible that the ecosystem at the investigated site was used for grazing in the form of pasture woodland. This hypothesis is supported by the dominance of Pomatias rivularis in sample 2, since Uherkovich et al. (2008) showed that this species is well adapted to disturbed and anthropogenically influenced habitats. Despite the moderately high species richness in this sample indicating a high diversity of habitats within the archived period, the massive occurrence of Pomatias rivularis may point to a disturbed ecosystem. Human impact is also supported by numerous archeological finds in Ahb1, where sample 2 was taken from, indicating a settlement at this place during at least a part of the formation time of Ahb1. Sample 1 shows again a decline in woodland species in favor of open-country species.

The constant absence of the wetland species Galba truncatula and Oxyloma elegans in the older samples (12-6) and their presence in most of the younger samples (5-1) is in accordance with a suggested shift of the river course towards the investigated site during the Late Holocene.

\subsection{Comparison of the Holocene gastropod assemblages with other local and regional studies}

\subsubsection{Vegetation history of the upper Alazani floodplain}

The gastropod assemblages in our fluvial sediment sequence at the upper Alazani River between samples 12 (Ahb6) and 10 (Ahb5) indicate that the landscape in the surroundings of the investigated site was covered by grassland during the Early Holocene until ca. 5.5 cal kyr BP. In samples 9 and 8 (Ahb4) a first species characteristic for open shrub to woodlands, Harmozica ravergiensis, appeared, but the assemblages were still dominated by open-country species. These findings confirm a former $n$-alkane-based vegetation reconstruction of Bliedtner et al. (2018a), where paleosols Ahb6 to Ahb4 also showed a local grass- and herb-dominated vegetation signal compared with the proportion of deciduous trees and shrubs (Fig. 5). In contrast to the $n$-alkanes that are generally not sensitive towards coniferous forests and would rather reflect the grassy undergrowth in coniferous forests (Diefendorf et al., 2011), the gastropod assemblages trace the distribution of open country versus woodland, irrespective of whether the latter was formed by deciduous or coniferous trees (Kralka, 1986; Dedov, 2008). Therefore, our gastropod assemblages corroborate the formerly suggested grass and herb dominance in the upper Alazani floodplain during the Early and Middle Holocene. This confirms the very different local vegetation history of the upper Alazani floodplain compared with the neighboring Iori floodplain ca. $40 \mathrm{~km}$ to the south. In the latter, pollen analyses showed a dominance of deciduous and coniferous forest vegetation from about $12.8 \mathrm{cal}$ kyr BP, and Salix propor- tions between $10 \%$ and $30 \%$ demonstrate that the pollen signal should mostly originate from the floodplain and not from the surrounding landscape (Gogichaishvili, 1984). In a wider regional context, the vegetation history of the upper Alazani floodplain is also different compared to Lesser Caucasus and Anatolian plateau, where pollen from lake and peat sediments suggest that reforestation started during the Early Holocene, although relatively late compared with central Europe, at 9-8 cal kyr BP (Wick et al., 2003; Messager et al., 2013, 2017; Joannin et al., 2014; Leroyer et al., 2016). However, while ecological and climatic conditions of the upper Alazani floodplain differ from the Lesser Caucasus and Anatolia, they are similar to the Iori floodplain. Thus, the most likely explanation for the different local vegetation histories in both neighboring floodplains is local human activity in the upper Alazani valley. Accordingly, numerous archeological findings (potsherds, obsidian tools, charcoal and an in situ fireplace) in the upper part of paleosol Ahb6 (position of sample 12) that were dated to $8.0-8.2$ cal kyr BP indicate local human occupation during that period, and singular potsherds were also found in the sediment layer between Ahb5 and Ahb4 (position of sample 9) as well as in paleosol Ahb4 (position of sample 8). The regional potential natural vegetation of the upper Alazani floodplain consists of riparian forests in the floodplain passing over into elm-oakvine forests at the slopes (Connor and Kvavadze, 2008), but unlike in the neighboring Iori floodplain this potential natural vegetation did not develop at the investigated site until ca. 4.5 cal kyr BP. Therefore, although we cannot derive intensity and permanence of late-Neolithic-Chalcolithic settlement and of the following periods from the relatively sparse available archeological data, we suggest that human activity from that time most likely hindered local afforestation at this site for several millennia. However, the distribution map of late-Neolithic-Chalcolithic settlement areas in the southern Caucasus of Akhundov (2004) does not show human activity in the upper Alazani floodplain (Fig. 6a). The earliest known archeological evidence directly from the upper Alazani valley is a Middle Bronze Age burial mound in the village Zemo Alvani ca. $4 \mathrm{~km}$ northwest of the studied site that was built around $3.8 \mathrm{ka}$ (Dedabrishvili and $\mathrm{Ru}-$ sishvili, 1980; Fig. 1b). In contrast, other regions of the southeastern Caucasus, including the lower Alazani region next to the Azerbaijan border, were settled by late-NeolithicChalcolithic cultures (Varazashvili, 1980, 1984; Chataigner et al., 2014; Lyonnet et al., 2016; Hamon et al., 2016; von Suchodoletz and Faust, 2018; Fig. 6a). We suggest that thus far missing knowledge about late-Neolithic-Chalcolithic settlement activities in the upper Alazani floodplain with favorable environmental conditions for human settlement was caused by the several-meter-thick cover of floodloam that had buried the contemporary settlement remains in paleosol Ahb6 (Fig. 1d). Similarly, thick coverages of prehistoric settlements with younger floodloam, leading to missing knowledge about prehistoric settlement patterns, are also known 
from other floodplains (Händel, 1967; Brown, 1997; Bard, 2015).

As indicated by the gastropod assemblages, increased reforestation towards an open woodland at the investigated site started within the sediment layer between Ahb4 and Ahb3 that was deposited around 4.5 cal kyr BP (sample 7) and lasted at least until ca. 3 cal kyr BP (sample 3, between Ahb2 and Ahb1). Unfortunately, for this period no comparison with $n$-alkane biomarkers is possible: whereas no $n$ alkane biomarker signal was obtained from paleosol Ahb3 (position of sample 6), the $n$-alkane signal from paleosol Ahb2 (position of sample 4) is not dominated by a local but an inherited catchment-derived biomarker signal because of the short time of pedogenesis of only some decades. Therefore, the $n$-alkanes from Ahb2 should not be interpreted (Bliedtner et al., 2018a; Fig. 5). Large parts of the southern Caucasus including the region surrounding the upper Alazani valley were settled by the Early Bronze Age Kura-Araxes (or Early Transcaucasian) culture from about $5.5 \mathrm{cal} \mathrm{kyr} \mathrm{BP}$ (Akhundov, 2004; Kohl, 2009; Fig. 6b). Therefore, this vegetation change was assumedly caused by local abandonment of human land use at the investigated site despite ongoing regional settlement activity or by less intensive land use in the form of pasture woodlands (see Sect. 5.1)

A further change of the gastropod assemblages occurred in paleosol Ahb1 (position of sample 2) that had developed between ca. 3 and 1.7 cal kyr BP: in this soil, gastropod species indicative of forests to open woodland are found together with a significant percentage of grassland species (Fig. 3). This indicates a change towards an even more open forest with larger proportions of grassland. It is very likely that this was caused by resuming human activity at this site or an intensification of land use, respectively. Increasing human activity at this site or in its surroundings for this time is also supported by numerous Iron Age archeological findings (potsherds, obsidian tools and charcoal) from the upper part of Ahb1 (Fig. 2). Furthermore, from this period burials with Scythian grave goods are known from the Alazani valley (Mamaiashvili, 1980). However, despite a dominance of open-woodland gastropod species, the $n$-alkane biomarker signal of paleosol Ahb1, averaging over the total period of soil development of ca. $1 \mathrm{ka}$, shows a local dominance of grasses and herbs (Bliedtner et al., 2018a; Fig. 5). Possible causes could be that (i) during most of this time grasses and herbs clearly dominated over the forest vegetation, as is suggested by a part of the gastropod assemblage, or (ii) the local woodland vegetation was dominated by coniferous trees that do not give an $n$-alkane biomarker signal (Diefendorf et al., 2011). However, the latter explanation is rather unlikely, given that the dominating gastropod species in this sample, Pomatias rivularis, typically lives in leaf litter of deciduous trees (Kerney et al., 1983). In the uppermost sample 1 no woodland species are found anymore, indicating opencountry vegetation similar to the current ecosystem.

\subsubsection{Possible shift of the Alazani River course during the Late Holocene}

Wetland species of gastropods are absent from the lower part of the investigated sequence. In contrast, they occur from sample 5 upwards, i.e., since ca. $4 \mathrm{cal} \mathrm{kyr} \mathrm{BP.} \mathrm{This} \mathrm{indicates}$ that the investigated site was relatively far away from the active riverbed during the Early and Middle Holocene and that the river approached towards the site during the Late Holocene (Fig. 7a and b). Morphologically young former river channels were observed up to $1.5 \mathrm{~km}$ north of the current river channel (Fig. 1b and c). Furthermore, the region shows a high regional tectonic activity linked with orogenesis at the southern margin of the Greater Caucasus (Forte et al., 2014), forming the base for river shifts linked with tectonic activity. Accordingly, strong earthquakes that have hit the Alaverdi Monastery located ca. $2 \mathrm{~km}$ east of the study site are documented for the 15th and 18th centuries CE (Gamkrelidze et al., 2013; Fig. 7a). Therefore, such a river shift towards the south during the Late Holocene was already formerly suggested by von Suchodoletz et al. (2018b) to explain strong incision of the sequence that finally led to the deactivation of the fluvial archive from ca. $1.6 \mathrm{cal} \mathrm{kyr}$ BP. The increasing presence of wetland gastropod species in the upper part of the sequence confirms this formerly suggested southern shift of the river course during the Late Holocene that was probably linked with orogenesis at the southern margin of the Greater Caucasus. However, the slowly increasing proportion of water-related gastropod species indicates that the shift of the river course must have occurred slowly rather than abruptly as was formerly suggested by von Suchodoletz et al. (2018b), i.e., in the form of preferential lateral migration (combing) as a response to lateral tilting of the floodplain (Holbrook and Schumm, 1999).

\section{Conclusions}

Our investigations of gastropod assemblages from a Holocene fluvial sediment-paleosol sequence at the upper Alazani River in the southeastern Caucasus region demonstrate that the studied site in the floodplain was free of the natural forest vegetation during the Middle Holocene until ca. $4.5 \mathrm{cal}$ kyr BP. This contrasts with a pollen-based Early to Middle Holocene vegetation reconstruction in the neighboring Iori floodplain, showing that this floodplain was covered with deciduous and coniferous forests from the Late Pleistocene. Thus, our gastropod data support former $n$ alkane biomarker analyses that are potentially biased due to their missing sensitivity towards coniferous trees and shrubs. Therefore, our data confirm open grass and herb vegetation during that period. We suggest that the open vegetation in the upper Alazani valley was probably caused by continuous settlement activity. Although intensity and permanence of local settlement activity could not be determined from our data, local human activity is also indicated by archeological finds 


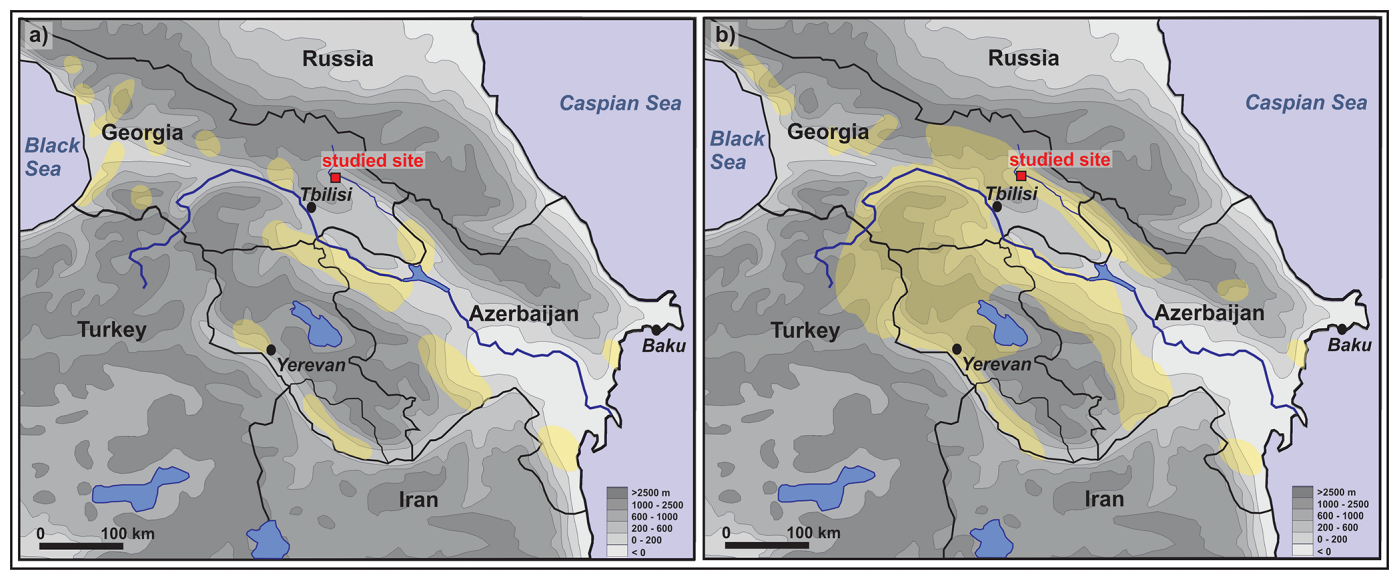

Figure 6. Map of settled regions in the southern Caucasus during different prehistoric periods after Akhundov (2004). (a) Late NeolithicChalcolithic (ca. 8.4-6.3 cal kyr BP) and (b) Kura-Araxes (Early Transcaucasian) culture (ca. 5.5-4.4 cal kyr BP).

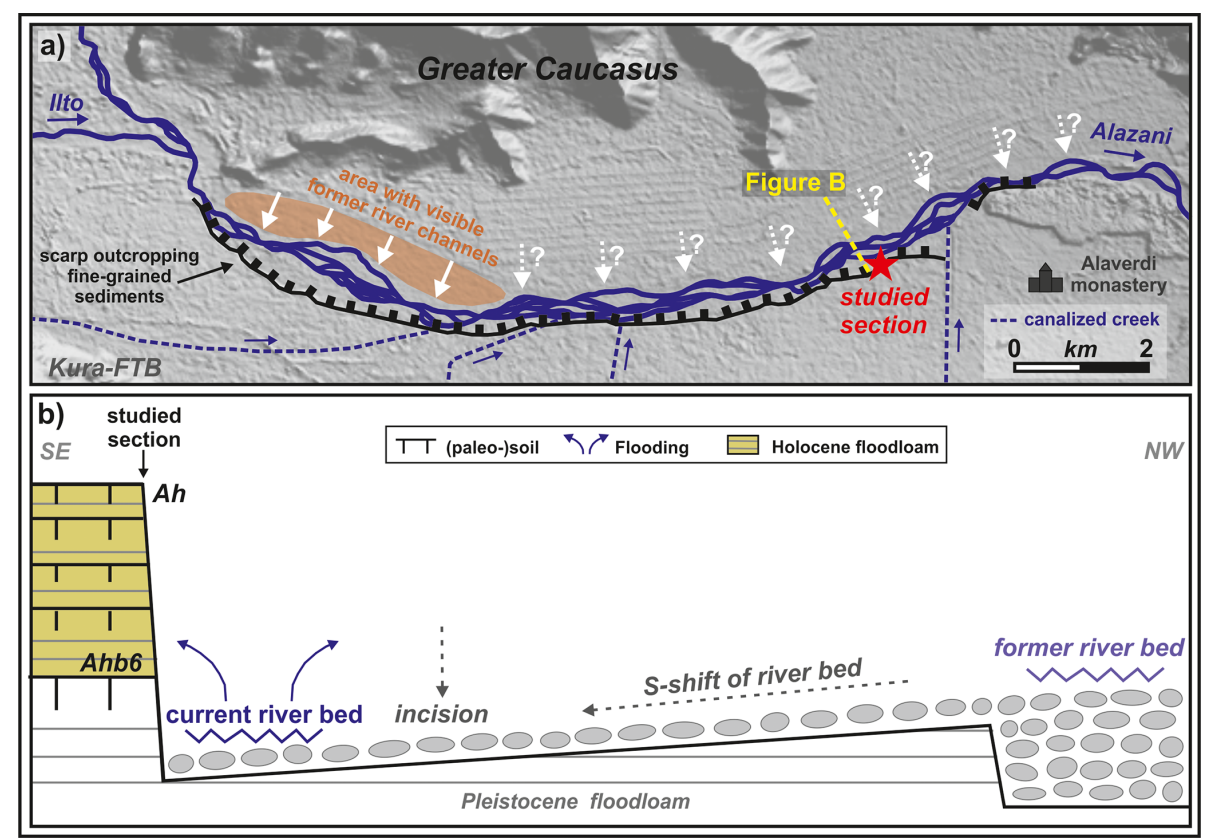

Figure 7. (a) Map of the suggested Late Holocene river shift (white arrows). (b) Model of the suggested river shift (adapted from von Suchodoletz et al., 2018b).

in the sequence. Therefore, by using a combination of land snail and $n$-alkane biomarker analyses of the studied fluvial sequence, it is possible that we identified a settlement center in the upper Alazani floodplain that was populated from the late Neolithic-Chalcolithic. This center was not known thus far, since the archeological remains are currently covered by several meters of floodloam that hindered their detection during archeological surface surveys. Therefore, our findings suggest that the area in the southern Caucasus region that was settled during the late-Neolithic-Chalcolithic period must have been larger than was known thus far. Furthermore, increasing contributions of wetland gastropod species since ca. 4 cal kyr BP confirm a local shift of the river course towards the investigated site throughout the Late Holocene that was possibly linked with ongoing regional tectonic activity. However, in contrast to former suggestions our gastropod assemblages indicate that this process was obviously slow and not abrupt. Altogether, our investigations demonstrate the high value of gastropod assemblages for geoarcheological and geomorphological Holocene floodplain research in regions with carbonatic river sediments at both a local and regional spatial scale. 
Data availability. A detailed list of the gastropod species in the studied sequence can be found in Table S1 in the Supplement.

Supplement. The supplement related to this article is available online at: https://doi.org/10.5194/egqsj-69-247-2020-supplement.

Author contributions. HvS, BH and CR designed the study. HvS carried out the fieldwork and was the main author of the paper. $\mathrm{CR}, \mathrm{FW}$ and $\mathrm{BH}$ determined and classified the gastropod species. MB contributed the $n$-alkane biomarker part, and ME and LL contributed the archeological part. All authors participated in the discussion of the results and the writing process.

Competing interests. The authors declare that they have no conflict of interest.

Acknowledgements. We thank Anna Skokan and Ulrich Göres (both Dresden) and Azra Khosravichenar (Leipzig) for their help during the fieldwork and Dominik Faust (Dresden) for his permanent support of the studies in eastern Georgia during the last years. We are grateful to the archeologists of the Georgian National Museum, Gia Chilingarashvili and Davit Darejanashvili, for providing scanned copies of the archeological literature while the libraries were inaccessible due to the COVID-19 pandemic. Furthermore, we thank two anonymous reviewers for their valuable comments on an early version of this paper. We acknowledge support from Leipzig University for open-access publishing.

Review statement. This paper was edited by Jan-Hendrik May and reviewed by two anonymous referees.

\section{References}

Adamia, S., Alania, V., Chabukiani, A., Chichua, G., Enukidze, O., and Sadradze, N.: Evolution of the late Cenozoic basins of Georgia (SW Caucasus): a review, in: Sedimentary basin tectonics from the Black Sea and Caucasus to the Arabian Platform, edited by: Sosson, M., Kaymkci, N., Stephenson, R. A., Bergerat, F., and Starostenko, V., Geological Society London Special Publications, London, UK, 239-259, 2010.

Akhundov, T.: South Caucasus in the Neolithic and Early Bronze Age: The question of epochs and periods, in: A view from the highlands: Archeological studies in honour of Charles Burney, edited by: Sagona, A., Peeters Publishers, Leuven, Belgium, 421-436, 2004.

Alexandrowicz, W. P.: Molluscan communities in Late Holocene fluvial deposits as an indicator of human activity: A study in Podhale basin in South Poland, Ekologia Bratislava, 32, 111-125, https://doi.org/10.2478/eko-2013-0010, 2013.

Avsin, N., Vandenberghe, J., van Balen, R., Kiyak, N. G., and Öztürk, T.: Tectonic and climatic controls on Quaternary fluvial processes and river terrace formation in a Mediterranean set- ting, the Göksu River, southern Turkey, Quat. Res., 91, 533-547, https://doi.org/10.1017/qua.2018.129, 2019.

Babek, O., Sedlacek, J., Novak, A., and Letal, A.: Electrical resistivity imaging of anastomosing river subsurface stratigraphy and possible controls of fluvial style change in a grabenlike basin, Czech Republic, Geomorphology, 317, 139-156, https://doi.org/10.1016/j.geomorph.2018.05.012, 2018.

Bakker, M. A. J., Maljers, D., and Weerts, H. J. T.: Ground-penetrating radar profiling on embanked floodplains, Neth. J. Geosci., 86, 55-61, https://doi.org/10.1017/S0016774600021314, 2007.

Bard, K. A.: An Introduction to the Archaeology of Ancient Egypt, Second Edn., Wiley Blackwell, Chichester, UK, 2015.

Bliedtner, M., Zech, R., Kühn, P., Schneider, B., Zielhofer, C., and von Suchodoletz, H.: The potential of leaf wax biomarkers from fluvial sediment-paleosol sequences for paleovegetation reconstructions - Upper Alazani River, central southern Greater Caucasus (Georgia), Quat. Sci. Rev., 196, 62-79, https://doi.org/10.1016/j.quascirev.2018.07.029, 2018a.

Bliedtner, M., Schäfer, I. K., Zech, R., and von Suchodoletz, H.: Leaf wax $n$-alkanes in modern plants and topsoils from eastern Georgia (Caucasus) - implications for reconstructing regional paleovegetation, Biogeosciences, 15, 3927-3936, https://doi.org/10.5194/bg-15-3927-2018, 2018b.

Bliedtner, M., von Suchodoletz, H., Schäfer, I., Welte, C., Salazar, G., Szidat, S., Haas, M., Dubois, N., and Zech, R.: Age and origin of leaf wax $n$-alkanes in fluvial sediment-paleosol sequences and implications for paleoenvironmental reconstructions, Hydrol. Earth Syst. Sci., 24, 2105-2120, https://doi.org/10.5194/hess-242105-2020, 2020.

Bridgland, D. and Westaway, R.: Climatically controlled river terrace staircases: A worldwide Quaternary phenomenon, Geomorphology, 98, 285-315, https://doi.org/10.1016/j.geomorph.2006.12.032, 2008.

Brown, A. G.: Alluvial geoarchaeology: Floodplain archaeology and environmental change, Cambridge University Press, Cambridge, UK, 1997.

Bush, R. T. and McInerney, F. A.: Leaf wax $n$-alkane distributions in and across modern plants: implications for paleoecology and chemotaxonomy, Geochim. Cosmochim. Ac., 117, 161-179, https://doi.org/10.1016/j.gca.2013.04.016, 2013.

Chataigner, C., Badalyan, R., and Arimura, M.: The Neolithic of the Caucasus, Oxford Handbooks Online, Oxford, UK, https://doi.org/10.1093/oxfordhb/9780199935413.013.13, 2014.

Connor, S. E. and Kvavadze, E. V.: Modelling late Quaternary changes in plant distribution, vegetation and climate using pollen data from Georgia, Caucasus, J. Biogeogr., 36, 529-545, https://doi.org/10.1111/j.1365-2699.2008.02019.x, 2008.

Connor, S. E., Colombaroli, D., Confortini, F., Gobet, E., Ilyashuk, B. P., Ilyashuk, E. A., van Leeuwen, J. F. N., Lamentowicz, M., van der Knaap, W. O., Malysheva, E., Marchetto, A., Margalitadze, N., Mazei, Y., Mitchell, E. A. D., Payne, R. J., and Ammann, B.: Long-term population dynamics: Theory and reality in a peatland ecosystem, J. Ecol., 106, 333-346, https://doi.org/10.1111/1365-2745.12865, 2018.

Dedabrishvili, S. and Rusishvili, R.: Zemo Alvani Middle Bronze Age burial, in: Reports of the Kakheti Archaeological Expedition, IV, edited by: Pitskhelauri, K., Metsniereba, Tbilisi, Georgia, 45-49, 1980. 
Dedov, I.: Terrestrial gastropods (Mollusca, Gastropoda) of the Bulgarian part of the Alibotush Mts., Malacologica Bohemoslovaka, 7, 17-20, 2008.

Diefendorf, A. F., Freeman, K. H., Wing, S. L., and Graham, H. V.: Production of $n$-alkyl lipids in living plants and implications for the geologic past, Geochim. Cosmochim. Ac., 75, 7472-7485, https://doi.org/10.1016/j.gca.2011.09.028, 2011.

Faust, D. and Wolf, D.: Interpreting drivers of change in fluvial archives of the Western Mediterranean - a critical view, Earth Sci. Rev., 174, 53-83, https://doi.org/10.1016/j.earscirev.2017.09.011, 2017.

Faust, D., Yanes, Y., Willkommen, T., Roettig, C., Richter, D., Richter, D., von Suchodoletz, H., and Zöller, L.: A contribution to the understanding of late Pleistocene dune sand-paleosolsequences in Fuerteventura (Canary Islands), Geomorphology, 246, 290-304, https://doi.org/10.1016/j.geomorph.2015.06.023, 2015.

Forte, A. M., Cowgill, E., Bernardin, T., Kreylos, O., and Hamann, B.: Late Cenozoic deformation of the Kura fold-thrust belt, southern Greater Caucasus, Geol. Soc. Am. Bull., 122, 465-486, https://doi.org/10.1130/B26464.1, 2010.

Forte, A. M., Cowgill, E., and Whipple, K. X.: Transition from a singly vergent to doubly vergent wedge in a young orogen: The Greater Caucasus, Tectonics, 33, 2077-2101, https://doi.org/10.1002/2014TC003651, 2014.

Fuchs, M., Will, M., Kunert, E., Kreutzer, S., Fischer, M., and Reverman, R.: The temporal and spatial quantification of Holocene sediment dynamics in a meso-scale catchment in northern Bavaria, Germany, Holocene, 21, 1093-1104, https://doi.org/10.1177/0959683611400459, 2011.

Fuhrmann, R.: Die Ostrakoden- und Molluskenfauna des Auelehmprofils Zeitz (Landkreis Burgenland) und ihre Aussage zum Klima sowie zur Landnutzung im jüngeren Holozän Mitteldeutschlands, Mauritiana, 20, 253-281, 2008.

Gamkrelidze, G. D., Mindorashvili, Z., Bragvadze, M., and Kvachadze, M.: A topoarchaeological dictionary of Kartlis Tskhovreba (The history of Georgia), Bakur Sulakauri Press, Tbilisi, Georgia, 2013.

Giosan, L., Clift, P. D., Macklin, M. G., Fuller, D. Q., Constantinescu, S., Durcan, J. A., Stevens, T., Duller, G. A. T., Tabrez, A. R., Gangal, K., Adhikari, R., Alizai, A., Filip, F., van Laningham, S., and Syvitsky, J. P. M.: Fluvial landscapes of the Harappan civilization, P. Natl. Acad. Sci., 109, 1688-1694, https://doi.org/10.1073/pnas.1112743109, 2012.

Gogichaishvili, L. K.: Vegetational and climatic history of the western part of the Kura River Basin, in: Palaeoclimates, Palaeoenvironments and Human Communities in the Eastern Mediterranean Region in Later Prehistory, edited by: Bintliff, J. L. and Van Zeist, W., BAR International Series, Oxford, UK, 325-341, 1984.

Granai, S. and Limondin-Lozouet, N.: The Holocene expansion of grassland in northern Europe reconstructed from molluscan assemblages, Boreas, 47, 768-779, https://doi.org/10.1111/bor.12304, 2018.

Hamon, C., Jalabadze, M., Agapishvili, T., Baudouin, E., Koridze, I., and Messager, E.: Gadachrili Gora: Architecture and organisation of a Neolithic settlement in the middle Kura Valley (6th millennium BC, Georgia), Quat. Int., 395, 154-169, https://doi.org/10.1016/j.quaint.2015.01.055, 2016.
Händel, D.: Das Holozän in den nordwestsächsischen Flußauen, Hercynia N.F., 4, 152-198, 1967.

Hassan, F. A.: The dynamics of a riverine civilization: A geoarchaeological perspective on the Nile Valley, Egypt, World Archaeol., 29, 51-74, 1997.

Holbrook, J. and Schumm, S. A.: Geomorphic and sedimentary response of rivers to tectonic deformation: a brief review and critique of a tool for recognizing subtle epeirogenic deformation in modern and ancient settings, Tectonophysics, 305, 87-306, https://doi.org/10.1016/S0040-1951(99)00011-6, 1999.

Joannin, S., Ali, A., Ollivier, V., Roiron, P., Peyron, O., Chevaux, S., Nahapetyan, S., Tozalakyan, P., Karakhanyan, A., and Chataigner, C.: Vegetation, fire and climate history of the Lesser Caucasus: A new Holocene record from Zarishat fen (Armenia), J. Quaternary Sci., 29, 70-82, https://doi.org/10.1002/jqs.2679, 2014.

Juřičková, L., Horáčková, J., Ložek, V., and Horsák, M.: Impoverishment of recent floodplain forest mollusc fauna in the lower Ohře River (Czech Republic) as a result of prehistoric human impact, Boreas, 42, 932-946, https://doi.org/10.1111/bor.12006, 2013.

Juřičková, L., Horsák, M., Horáčková, J., Abraham, V., and Ložek, V.: Patterns of land-snail succession in Central Europe over the last 15,000 years: main changes along environmental, spatial and temporal gradients, Quat. Sci. Rev., 93, 155-166, https://doi.org/10.1016/J.QUASCIREV.2014.03.019, 2014.

Kerney, M. P., Cameron, R. A. D., and Jungbluth, J. H.: Die Landschnecken Nord- und Mitteleuropas, Paul Parey, Hamburg and Berlin, Germany, 1983.

Kittel, P., Plociennik, M., Borowka, R. K., Okupny, D., Pawlowski, D., Peyron, O., Stachowicz-Rybka, R., Obremska, M., and Cywa, K.: Early Holocene hydrology and environments of the Ner River (Poland), Quat. Res., 85, 187-203, https://doi.org/10.1016/j.yqres.2015.12.006, 2016.

Kohl, P. L.: Origins, homelands and migrations: Situating the Kura-Araxes Early Transcaucasian 'Culture' within the history of Bronze Age Eurasia, Tel Aviv, 36, 241-265, https://doi.org/10.1179/033443509x12506723940686, 2009.

Kralka, R. A.: Population characteristics of terrestrial gastropods in boreal forest habitats, Am. Midl. Nat., 115, 156-164, 1986.

Lahijani, H. A. K., Rahimpour-Bonab, H., Tavakoli, V., and Hosseindoost, M.: Evidence for late Holocene highstands in Central Guilan-East Mazanderan, South Caspian coast, Iran, Quat. Int., 197, 55-71, https://doi.org/10.1016/j.quaint.2007.10.005, 2009.

Lauer, T., Weiss, M., Bernhardt, W., Heinrich, S., Rappsilber, I., Stahlschmidt, M., von Suchodoletz, H., and Wansa, S.: The Middle Pleistocene fluvial sequence at Uichteritz, central Germany: chronological framework, paleoenvironmental history and evidence for human presence during MIS 11, Geomorphology, 354, 107016, https://doi.org/10.1016/j.geomorph.2019.107016, 2020.

Leroyer, C., Joannin, S., Aoustin, D., Ali, A. A., Peyron, O., Ollivier, V., Tozalakyan, P., Karakhanyan, A., and Jude, F.: Mid Holocene vegetation reconstruction from Vanevan peat (southeastern shore of Lake Sevan, Armenia), Quat. Int., 395, 5-18, https://doi.org/10.1016/j.quaint.2015.06.008, 2016.

Ložek, V.: Quartärmollusken der Tschechoslowakei, Rozpr. Ústřed. Ústavu Geol., Prague, Czech Republic, 1964. 
Ložek, V.: Molluscs in loess, their paleoecological significance and role in geochronology - Principles and methods, Quat. Int., 7/8, 71-79, https://doi.org/10.1016/1040-6182(90)90040-B, 1990.

Lydolph, P. E.: Climates of the Soviet Union, World Survey of Climatology, Vol. 7, Elsevier, Amsterdam, the Netherlands, 1977.

Lyonnet, B., Guliyev, F., Bouquet, L., Bruley-Chabot, G., Samzun, A., Pecqueur, L., Jovenet, E., Baudouin, E., Fontugne, M., Raymond, P., Degorre, E., Astruc, L., Guilbeau, D., Le Dosseur, G., Benecke, N., Hamon, C., Poulmarch, M., and Courcier, A.: Mentesh Tepe, an early settlement of the ShomuShulaveri Culture in Azerbaijan, Quat. Int., 395, 170-183, https://doi.org/10.1016/j.quaint.2015.02.038, 2016.

Mamaiashvili, N.: Burials with Scythian grave goods from the IoriAlazani basin, in: Reports of the Kakheti Archaeological Expedition IV, edited by: Pitskhelauri, K., Metsniereba, Tbilisi, Georgia, 103-115, 1980.

Messager, E., Belmecheri, S., von Grafenstein, U., Nomade, S., Ollivier, V., Voinchet, P., Puaud, S., Courtin-Nomade, A., Guillou, H., Mgeladze, A., Dumoulin, J.-P., Mazuy, A., and Lordkipanidze, D.: Late Quaternary record of the vegetation and catchment-related changes from Lake Paravani (Javakheti, South Caucasus), Quat. Sci. Rev., 77, 125-140, https://doi.org/10.1016/j.quascirev.2013.07.011, 2013.

Messager, E., Nomade, S., Wilhelm, B., Joannin, S., Scao, V., von Grafenstein, U., Martkoplishvili, I., Ollivier, V., Mgeladze, A., Dumoulin, J.-P., Mazuy, A., Belmecheri, S., and Lordkipanidze, D.: New pollen evidence from Nariani (Georgia) for delayed postglacial forest expansion in the South Caucasus, Quat. Res., 87, 121-132, https://doi.org/10.1017/qua.2016.3, 2017.

Mlekuz, D. and Budja, M.: Lake or floodplain? Mid-Holocene settlement patterns and the landscape dynamic of the Ižica floodplain (Ljubljana Marshes, Slovenia), Holocene, 20, 1269-1275, https://doi.org/10.1177/0959683610371998, 2010.

Moine, O., Rousseau, D.-D., and Antoine, P.: The impact of Dansgaard-Oeschger cycles on the loessic environment and malacofauna of Nussloch (Germany) during the Upper Weichselian, Quat. Res., 70, 91-104, https://doi.org/10.1016/j.yqres.2008.02.010, 2008.

Morozova, G. S.: A review of Holocene avulsions of the Tigris and Euphrates Rivers and possible effects on the evolution of civilizations in Lower Mesopotamia, Geoarchaeology, 20, 401-423, https://doi.org/10.1002/gea.20057, 2005.

Mumladze, L., Asanidze, Z., Walther, F., and Hausdorf, B.: Beyond elevation: testing the climatic variability hypothesis vs. Rapoport's rule in vascular plant and snail species in the Caucasus, Biol. J. Linn. Soc., 121, 753-763, https://doi.org/10.1093/biolinnean/blx027, 2017.

Murelaga, X., Ortega, L. A., Sancho, C., Munoz, A., Osacar, C., and Larraz, M.: Succession and stable isotope composition of gastropods in Holocene semi-arid alluvial sequences (Bardenas Reales, Ebro Basin, NE Spain): Palaeoenvironmental implications, Holocene, 22, 1047-1060, https://doi.org/10.1177/0959683612437869, 2012.

Myšák, J. and Horsák, M.: Floodplain corridor and slope effects on land mollusc distribution patterns in a riverine valley, Acta Oecol., 37, 146-154, https://doi.org/10.1016/j.actao.2011.01.012, 2011.

New, E., Yanes, Y., Cameron, R. A. D., and Miller, J. H.: Aminochronology and time averaging of Quaternary land snail assemblages from colluvial deposits in the Madeira Archipelago, Portugal, Quat. Res., 92, 483-496, https://doi.org/10.1017/qua.2019.1, 2019.

Pokryszko, B. M., Cameron, R. A., Mumladze, L., and Tarkhnishvili, D.: Forest snail faunas from Georgian Transcaucasia: patterns of diversity in a Pleistocene refugium, Biol. J. Linn. Soc., 102, 239-250, https://doi.org/10.1111/j.10958312.2010.01575.x, 2011.

Richter, C., Roettig, C.-B., Wolf, D., Groh, K., Kolb, T., and Faust, D.: Changes in Pleistocene gastropod faunas on Fuerteventura (Canary Islands) and implications on shifting palaeoenvironmental conditions, Quat. Sci. Rev., 209, 63-81, https://doi.org/10.1016/j.quascirev.2019.02.005, 2019.

Schulte, L., Peña, J. C., Carvalho, F., Schmidt, T., Julià, R., Llorca, J., and Veit, H.: A 2600-year history of floods in the Bernese Alps, Switzerland: frequencies, mechanisms and climate forcing, Hydrol. Earth Syst. Sci., 19, 3047-3072, https://doi.org/10.5194/hess-19-3047-2015, 2015.

Scott, A. C., Hardiman, M., Pinter, N., Anderson, R. S., Daulton, T. L., Ejarque, A., Finch, P., and Carter-Champion, A.: Interpreting palaeofire evidence from fluvial sediments: a case study from Santa Rosa Island, California, with implications for the Younger Dryas Impact Hypothesis, J. Quaternary Sci., 32, 35 47, https://doi.org/10.1002/jqs.2914, 2016.

Syvitsky, J. P. M., Overeem, I., Brakenridge, G. R., and Hannon, M.: Floods, floodplains, delta plains - A satellite imaging approach, Sediment. Geol., 267/268, 1-14, https://doi.org/10.1016/j.sedgeo.2012.05.014, 2012.

Uherkovich, A., Purger, D., and Csiky, J.: First find of Pomatias rivularis (Eichwald, 1829) (Mollusca: Pomatiidae) in Croatia, Natura Croatica, 17, 183-192, 2008.

van de Velde, S., Wesselingh, F. P., Yanina, T. A., Anistratenko, V. V., Neubauer, T. A., ter Poorten, J. J., Vonhof, H. B., and Kroonenberg, S. B.: Mollusc biodiversity in late Holocene nearshore environments of the Caspian Sea: A baseline for the current biodiversity crisis, Palaeogeogr. Palaeocl., 535, 109364, https://doi.org/10.1016/j.palaeo.2019.109364, 2019.

Varazashvili, V.: Materials of the mid-4th millennium BC from IoriAlazani basin, in: Reports of the Kakheti Archaeological Expedition, IV, edited by: Pitskhelauri, K., Metsniereba, Tbilisi, Gorgia, $18-44,1980$.

Varazashvili, V.: Damtsvari Gora Settlement, in: Reports of the Kakheti Archaeological Expedition, VI, edited by: Pitskhelauri, K., Metsniereba, Tbilisi, Georgia, 19-26, 1984.

von Suchodoletz, H. and Faust, D.: Late Quaternary fluvial dynamics and landscape evolution at the lower Shulaveris Ghele River (southern Caucasus), Quat. Res., 89, 254-269, https://doi.org/10.1017/qua.2017.80, 2018.

von Suchodoletz, H., Menz, M., Kühn, P., Sukhishvili, L., and Faust, D.: Fluvial sediments of the Algeti River in southeastern Georgia - an archive of Late Quaternary landscape activity and stability in the Transcaucasian region, Catena, 130, 95-107, https://doi.org/10.1016/j.catena.2014.06.019, 2015.

von Suchodoletz, H., Gärtner, A., Zielhofer, C., and Faust, D.: Eemian and post-Eemian fluvial dynamics in the Lesser Caucasus, Quat. Sci. Rev., 191, 189-203, https://doi.org/10.1016/j.quascirev.2018.05.012, 2018a.

von Suchodoletz, H., Zielhofer, C., Hoth, S., Umlauft, J., Schneider, B., Zeeden, C., Sukhishvili, L., and Faust, 
D.: North Atlantic influence on Holocene flooding in the southern Greater Caucasus, Holocene, 28, 609-620, https://doi.org/10.1177/0959683617735584, 2018b.

Wick, L., Lemcke, G., and Sturm, M.: Evidence of Lateglacial and Holocene climatic change and human impact in eastern Anatolia: High-resolution pollen, charcoal, isotopic and geochemical records from the laminated sediments of Lake Van, Turkey, Holocene, 13, 665-675, https://doi.org/10.1191/0959683603hl653rp, 2003.
Zielhofer, C., Bussmann, J., Ibouhouten, H., and Fenech, K.: Flood frequencies reveal Holocene rapid climate changes (Lower Moulouya River, northeastern Morocco), J. Quaternary Sci., 25, 700-714, https://doi.org/10.1002/jqs.1347, 2010. 